\title{
REMI expression
}

\section{DNA preparation}

- Digest about $20 \mu \mathrm{g}$ of plasmid DNA with BamHI.

- Ethanol precipitate and resuspend in $20 \mu$ of $\mathrm{H}_{2} \mathrm{O}$ or TE buffer.

- Check DNA concentration on a nanodrop.

\section{Transfection}

- Pre-chill a $2 \mathrm{~mm}$ gap electroporation cuvette on ice.

- Prepare two $10 \mathrm{~cm}$ Petri dish (tissue culture treated) with $10 \mathrm{ml}$ SorMC buffer $+K$. aerogens at $\mathrm{OD}_{600}=2$

- Scrape $\sim 4 \cdot 10^{6}$ cells from the feeding front of an SM agar plate with a bacterial lawn or use a clearing plate.

- Transfer cells to an Eppendorf tube with $1 \mathrm{ml} \mathrm{H} 40$.

- Pipet cells up and down to get them into suspension (cells can be counted at this point, but exact numbers are not critical).

- Flash-spin cells 2 seconds 10,000 xg (or for 3 min @ 300 xg)

- Wash cells once in $\mathrm{H} 40$.

- Resuspend cells in $200 \mu \mathrm{l} \mathrm{H40.}$

- Place on ice and let cells cool down.

- Prepare two tubes with $2 \mu \mathrm{g}$ of BamHI digested DNA on ice.

- Prepare one tube with 5 units Dpnll on ice.

- Add the cells to the DNA. Mix by pipetting (this is the no-enzyme control).

- Transfer DNA/cell mixture to the electroporation cuvette.

- Zap the cells using the following square-wave settings. Make sure cells are ice-cold during the zap:

- $350 \mathrm{~V}$

- $8 \mathrm{~ms}$

- 2 pulses

- 1 second pulse interval

Without delay, transfer the cells to the $10 \mathrm{~cm}$ Petri dish (tissue culture treated).

- Add the cells to the DNA. Mix by pipetting.

- Add the DNA/cell suspension to the restriction enzyme. Mix by pipetting.

- Transfer the mixture to the electroporation cuvette (you can re-use the previous cuvette).

- Zap as above.

Without delay, transfer the cells to the $10 \mathrm{~cm}$ Petri dish (tissue culture treated). Expect round cells and $>90 \%$ survival. Optimal seeding density is about $10-20 \%$. Higher densities have the chance of aggregating before the selection marker is becoming effective. Cells will recover their normal morphology in about 30 minutes. 
After 5 hours, add selection marker.

Hygromycin $\quad 100 \mu \mathrm{g} / \mathrm{ml}$

The yield has been variable. We got clones numbers between 50 and 2000 for the positive plate. The best is to dispense the transfected cells in a 1:10 dilution series across three 96-wells plates to ensure single colonies per well. Expect clones after 5-7 days. 